\title{
DEFENSES TO PERFORMANCE OF INSTALLMENT CONTRACTS
}

When a party to an installment contract for the sale of goods has refused or failed to perform a duty arising from the contract, the nonbreaching party may have a right to declare himself discharged from all future obligation under the contract, or, a temporary right to suspend his own performance, without himself becoming liable for damages.

In jurisdictions where Section 45(2) of the Uniform Sales Act has been adopted, the nonbreaching party may declare himself discharged from future obligation if the breaching party's default is material. The proposed Uniform Commercial Code would not allow the nonbreaching party to declare himself discharged unless the breaching party's default substantially impaired the value of the whole contract to the nonbreaching party.

The right of the nonbreaching party temporarily to suspend his own performance, as distinguished from a permanent discharge from future obligation, is controlled by the common law.

This comment will attempt to define the facts that must be proved to obtain a discharge under the test of materiality provided by the Sales Act, and the extent to which those requirements might be changed by enactment of the Uniform Commercial Code. The inadequate state of the common law relating to the temporary right, arising from breach, to suspend performance will also be discussed.

\section{RIGHT TO DECLARE DISCHARGE}

Deciding whether an injured party to an installment contract is discharged from all future obligation to perform, by the breach of another party, is complicated by Section 45(2) of the Uniform Sales Act, which controls the decision in California ${ }^{1}$ and other jurisdictions which have adopted the Act. ${ }^{2}$

The statute provides that a party will be discliarged from future obligation under an installment contract by a material breach, and that materiality is to be determined from the facts and circumstances of the case. But the statute does not indicate which facts and circumstances are relevant to materiality and what tests may be employed to determine the rights of an injured party prior to litigation. ${ }^{3}$

1 CaL. Crv. Code $\$ 1765$.

2 Alabama, Alaska, Arizona, Arkansas, Colorado, Connecticut, Delaware, District of Columbia, Hawaü, Idaho, Illinois, Iowa, Kentucky, Maine, Maryland, Massachusetts, Michigan, Mimnesota, Nebraska, Nevada, New Hampshire, New Jersey, New York, North Dakota, Ohio, Oregon, Pennsylvania, Rhode Island, South Dakota, Tennessee, Utah, Washington, Wisconsin, and Wyoming.

3 Subdivision (2) of $\$ 45$ states:

"Where there is a contract to sell goods to be delivered by stated installments, which are to be separately paid for, and the seller makes defective deliveries in respect of one or more installments, or the buyer neglects or refuses to take delivery of or pay for one or more installments, it depends im each case on the terms of the contract and the circumstances of the case whether the breach of contract is so inaterial as to justify the imjured party in refusing to proceed further and suing for damages for breach of the entire contract, or whether the breach is severable, giving rise to a claim for compensation but not to a right to treat the whole contract as broken." 
While the Sales Act expressly provides that the terms of the contract are relevant to materiality ${ }^{4}$ and a term in the contract defining materiality has been held to control, ${ }^{5}$ an injured party may not be allowed to declare a discharge for a trivial breach, even though the contract seemingly so provides. ${ }^{6}$ But parties are free to deny themselves the right to discharge from breach, by a term in the contract. ${ }^{\text {? }}$

If the common law provides that, as to payment, time is of the essence in a mercantile contract, notwithstanding the absence of a term in the contract to that effect, New York ${ }^{8}$ and $\mathrm{Ohio}^{\circ}$ decisions indicate that the common law rule falls in the presence of the Sales Act and that the facts and circumstances of the case control. It has also been held that the Sales Act prevails ${ }^{10}$ over the "unequivocally declared"11 common law rule 12 that a single failure to pay or deliver discharged the injured party.

Although recent decisions from other jurisdictions have shed some light on the meaning of Section 45(2), no California case applying the section has been found. It may be that the heavy risk assumed by counsel in deciding whether a party is discharged from future obligation by a particular breach $^{13}$ has led many parties to settle their differences by negotiation, in preference to a resort to the courts. But the uncertainty that makes litigation ill-advised also makes negotiation difficult.

\section{Breaches That Discharge Seller}

While breaches by seller may include a multitude of sins, ${ }^{14}$ buyer's breaches customarily take the form of nonpayment..$^{15}$ Suppose that seller and buyer contract for the sale of 290,000 pounds of lead to be delivered in installments, payment to follow each delivery. Buyer pays for the first two deliveries and fails to pay for the third. Seller has enough lead on hand to complete the contract; buyer is solvent. On these facts the Third Circuit recently held the seller was not discharged: ${ }^{16}$

\footnotetext{
${ }^{4}$ See the statute, set out in note 3 supra.

5 Cadillac Machine Co. v. Mitchell-Diggens Iron Co., 205 Mich. 107, 171 N.W. 479 (1919).

6 Mancourt Winters Coal Co. v. Ford Motor Co., 236 Mich. 323, 210 N.W. 144 (1926).

7 Schminke v. Diamond Bros., 99 F.2d 467 (8th Cir. 1938).

8 Helgar Corp. v. Warners Features, 222 N.Y. 449, 119 N.E. 113 (1918).

0 Midwest Color Offset Co. v. Thermal Electric Corp., 116 Ohio 482, 156 N.E. 595 (1927).

10 Herx v. Carlson, 210 App. Div. 417, 206 N.Y. Supp. 179 (1st Dep't 1924); see also Miller v. Sergeant Co., 191 App. Div. 814, 182 N.Y. Supp. 382 (1st Dep't 1920); Kieckbefer Box Co. v. John Strange Paper Co., 180 Wis. 367, 193 N.W. 487 (1923) where the Wisconsin Supreme Court said that whatever the common law prior to the Sales Act might have been was unimportant, and that Section 45(2) would henceforth control in that jurisdiction.

11 Wolfert v. Caledomia Springs Ice Co., 195 N.X. 118, 88 N.E. 24 (1909).

12 Ibid.; Pope v. Porter, 102 N.X. 366, 7 N.E. 304 (1893).

13 One who incorrectly decides that a particular breach has discharged him from future obligation, and cancels the contract, has repudiated and becomes himself hable for damages. Lander v. Samuel Heller Leather Co., 314 Mass. 592, 50 N.E.2d 962 (1943).

14 E.g., late dehivery, delivery of defective goods, delivery of goods in improper quantity.

15 Stopping payment on a check is equivalent to nonpayment. Michaelson v. Thomas, 260 App. Div. 832, 22 N.X.S. 2d 364 (3d Dep't 1940). See quotation of Justice Cardozo, text infra at note 46.

16 Plotnick v. Pennsylvania Smelting and Refining Co., 194 F.2d 859 (3d Cir. 1952).
} 
We are dealing, therefore, with a situation in which the controlling statute explicitly inakes the circumstances of tle particular case determine whether failure to pay the price of one shipinent delivered ... justifies the seller in treating lis own obligation with reference to future installinents as ended. We think the key is to be found in the rational basis of the statute itself. The flexibility of the statute reflects the inpossibility of generalization about the consequences of failure to pay promptly for installments delivered. Yet, the commercial sense of the statute yields two guiding considerations. First, nonpayment for a . . . shipment nnay nake it impossible or unreasonably burdensome from a financial point of view for the seller, to supply future installments as promised. Second, buyer's breach of his proinise to pay for one installment may create sucl reasonable appreliension in the seller's mind concerning payment for future installments that seller should not be required to take the risk involved in continuing deliveries.

These elements would seem to be sound tests for the materiality of buyer's breach. Since the seller can always sue for payment due, ${ }^{17}$ if nonpayment neither causes him reasonably to doubt buyer's ability to perform nor makes it financially difficult to continue deliveries, there would seem to be no reason for allowing a discharge.

However, on the above facts, if the payment due was twenty-five hundred dollars, and seller had shown that claims pending against him made payment an urgent necessity, it would seem that this court would discharge seller. ${ }^{18}$ And while a seller may be discharged, upon buyer's failure to pay, because his financial position made prompt payment necessary, ${ }^{19}$ a seller will not be discharged if the urgency of his situation does not overcome the fundamental triviality of buyer's breach. Suppose that under a contract for delivery of ten thousand bushels of soy beans in installments, buyer is to furnish shipping instructions before each delivery. There is a shortage of railroad cars and seller is under pressure from a railroad to return the cars he leases to make deliveries. After a phone conversation with seller, buyer forwards shipping instructions forty-eight hours late. On these facts the Eighth Circuit sustained a directed verdict for buyer in his action against seller, where seller had claimed a discharge on the ground that buyer's delay was a material breach. ${ }^{20}$

\section{Privileged Nonpayment}

Under certain circumstances, a buyer may be privileged to refuse payment for a particular installment. If nonpayment is privileged, buyer has not breached, and no discharge, therefore, can arise.

Suppose that the contract requires seller to deliver leather of a certain

\footnotetext{
17 Helgar Corp. v. Warner's Features, 222 N.Y. 449, 119 N.E. 113 (1918).

18 A seller was discharged on similar facts involving a contract for the sale of coal. Gerber v. Ogle Coal Co., 195 Wis. 578, 218 N.W. 361 (1928).

10 Refining Co. v. Processing Co., 69 Ohio App. 175, 43 N.E.2d 311 (1942).

20 In view of the total volume of goods to be delivered under the contract and the nature and length of buyer's delay, the breacli was held immaterial as a matter of law. Simpson Feed Co. v. Continental Grain Co., 199 F.2d 284 (8th Cir. 1952); see also Benedict v. Harris, 158 Ore. 613, 77 P.2d 442 (1918).
} 
quality, payment to follow each dehivery. Seller ships defective leather in one installment and, after a dispute, demands payment. Buyer refuses payment and insists that seller continue to perform. On these facts the Massachusetts court has held that, because buyer's damages from the defective shipment were uncertain and could be determined only by litigation, buyer was privileged to refuse payment and seller was not discharged. ${ }^{21}$ The theory applied here allows a buyer to recoup damages from seller in diminution of the price for defective delivery. This would seem sound; if seller believes that buyer has diminished the price by a fair amount, then he need bring no action but if he believes that buyer has withheld too much he may litigate the issue.

Recoupment probably prevents many lawsuits. ${ }^{22}$ The limitation placed on recoupment by the Massachusetts court, that the amount of damage must be uncertain before the privilege to withhold arises, appears sound. If the damage caused by defective delivery can be easily calculated, buyer should not be permitted to withhold any excess. If, however, buyer's damage exceeded the price due, it would seem unlikely that a court would deny the privilege to withhold the entire price.

Buyer may be privileged to withhold payment and require that seller continue to perform, in the absence of payment, if some accident or disaster has made it temporarily impossible or impractical for buyer to identify his creditors and the amount owed each. Suppose that buyer's factory is destroyed by fire; his books are burned and seller is not paid because buyer has no information, pending investigation, as to the identity of his creditors or amounts owed. The New York Court of Appeals has indicated that these facts might privilege buyer to withhold payment, provided that he is actually unable to determine who his creditors are as a result of the fire, and provided that buyer notifies seller, if buyer knows his identity but not the amount owed, and enters into negotiation to settle the claim. ${ }^{23}$ But if the fire had an adverse effect on buyer's solvency, the result might be otherwise. ${ }^{24} \mathrm{~A}$ discharge might arise if a disaster so damaged buyer's assets that his capacity to complete the contract was impaired.

21 Lander v. Samuel Heller Leather Co., 314 Mass. 592, 50 N.E.2d 962 (1943). The decision relied on $\$ 69$ of the Act which allows a buyer to recoup damages for breach of warranty from the price. $\$ 69$ was held to apply to installment contracts in John Service Co. v. GoodnowPearson Co., 242 Mass. 594, 136 N.E. 623 (1920). See also Greer v. Oelhafen, 180 Wis. 131, 192 N.W. 467 (1923). Recoupment of damages from the price has the advantage of putting a breaching seller on the defensive in negotiation, while a failure to allow recoupment would put buyer in the difficult position of having to decide whether the breach was material while seller capitalized on the difficulty of the decision.

22 See, e.g., Goodyear Tire \& Rubber Co. v. Hershenstein, 221 App. Div. 592, 224 N.Y. Supp. 501 (1st Dep't 1927), rev'd on other grounds; noted in 34 HARv. L. REv. 329 (1921).

23 In Ferguson v. Chuck, 236 N.Y. 149, 140 N.E. 225 (1923), the court indicated that buyer might have been privileged to withhold payment, had the above facts been present, and then sustained a discharge for seller because buyer had a set of books after the fire which showed his debt to seller, and because he apparently failed to notify seller of any reason for nonpaynent.

24 See text at note 16 supra, for quotation from Plotnick v. Pennsylvania Smelting and Refining Co., 194 F.2d 859 (3d Cir. 1952), indicating that seller's right to a discharge may depend upon a reasonable apprehension that buyer will not perform in the future. Insolvency coupled with nonpayment may give rise to such an apprehension. 
The theoretical basis for the requirement that buyer be solvent before he is privileged to withhold payment" is discussed infra under "Temporary Privilege to Suspend Performance." The privilege is described here as an exception to seller's right to be discharged for nonpayment.

\section{Repudiation}

When buyer's nonpayment amounts to a repudiation of the entire contract, seller is discharged as a matter of law. ${ }^{28}$ The moral nature of buyer's conduct is, under the present law, to be taken into account in determining materiality. ${ }^{27}$ A deliberate refusal to pay, for no reason, is not only morally indefensible, but also raises a serious doubt as to whether buyer intends to complete his contract. Seller should not be required to complete his contract when he has good reason to believe that buyer has thrown over his own obligation. ${ }^{28}$

While the legal effect of repudiation seems clear, the more important question is the test for determining when particular conduct constitutes repudiation. Suppose that buyer, for no reason, refuses payment for one installment. The Wisconsin Supreme Court has held that where no dispute as to deliveries was present, and buyer gives no reason for the nonpayment, buyer's refusal constitutes repudiation and seller is entitled to a discharge as a matter of law. ${ }^{29}$ The result may be explained on the theory that buyer's act raised an inference that buyer did not intend to complete his contract. That this was the court's theory is demonstrated by the court's statement that if buyer had expressed an erroneous belief that he had a right to withhold payment his refusal might not discharge seller, as a matter of law.

It would seem to make a difference, in the determination of buyer's intent from a refusal to pay, if the contract price was a fixed amount as distmguished from the market price, and the market was falling. Suppose, under these circumstances, that buyer said to seller upon delivery of the first installment, "I don't want it." From this seller would have to determine whether buyer was merely refusing the one installment or repudiating the entire contract. If the former, seller would be required to show the materiality of buyer's breach as a matter of fact; if the latter, the breach would be material as a matter of law. ${ }^{30}$ Where the contract was for a fixed price, and the market was fallimg below the contract price, the New York Court of Appeals has held buyer's declaration "I don't want it" to be a repudiation of the entire contract that discharged seller. ${ }^{31}$

25 E.g., Hjorth v. Albert Lea Machinery Co., 142 Minn. 387, 172 N.W. 488 (1919) (buyer's right to withhold payment was conditioned upon his solvency).

26 Gedanke v. Wisconsin Evaporated Milk Co., 215 Wis. 370, 254 N.W. 660 (1934) ; Bahnsen v. Gerst, 235 N.Y. 426, 139 N.E. 563 (1923) ; Roberts v. Link, 142 Md. 676, 121 Atl. 633

(1923) ; Chess \& Wymond Co. v. LaCrosse Box Co., 133 Wis, 38, 181 N.W. 313 (1921).

27 Helgar Corp. v. Warner's Features, 222 N.Y. 449, 119 N.E. 113 (1918).

28 Cf. Plotnick v. Pennsylvania Smelting and Refining Co., 194 F.2d 859 (3d Cir. 1952).

20 Chess \& Wymond Co. v. LaCrosse Box Co., 173 Wis. 382, 181 N.W. 313 (1921).

30 Ibid.

31 Bahnsen v. Gerst, 235 N.Y. 426, 139 N.E. 563 (1923). The court's theory would seem to he that buyer's declaration manifested an intention to abandon the agreement and buy, at a lower price, on the open market. 
This decision strikes a warning for buyers who are working with a fixed price contract, when the market has fallen below the contract price, and who desire to reject or complain about one shipment without repudiating the entire contract and subjecting themselves to damages for breach of the whole contract. The seller should be put on notice that no repudiation of the entire contract is intended, but rather, that buyer's objection is to a single installment. The test for repudiation, therefore, may be and ought to be whether buyer's conduct manifests an intent not to complete the contract. Some courts ${ }^{32}$ may appear at first blush to have decided the question according to the moral nature of buyer's conduct, but the decisions seem actually to turn on the theory of the Wisconsin court that the buyer's intention controls.

However, to hold that a defaulting buyer has not repudiated does not necessarily deny seller a defense or other relief; in addition to being able to sue for damages for the particular breach ${ }^{33}$ seller may be discharged if he can show, as a matter of fact, that buyer's breach was nuaterial. ${ }^{\mathbf{3 4}}$

\section{Breaches That Discharge Buyer}

While seller is, generally, faced only with the problem of deciding the effect of nonpayment, buyer must deal with at least three customary forms of breach by seller: delivery of goods of defective quality, delivery of goods in a quantity different from the contract specifications, and delivery that is late. The two latter classes of breach may merge in the same problem because sellers who deliver late often tender more than one installment in one delivery. ${ }^{35}$

\section{Delivery of Goods of Defective Quality}

Where seller delivers defective goods, the subject matter of the delivery may be of great importance in determining materiality. Suppose a state contracts with a dairy for milk for a hospital. One installment, representing a small portion of the milk contracted for, is infested with maggots and generally unsanitary. Could seller argue successfully that his breach concerned too small a portion of the total anount of milk to be delivered to raise an inference that future performance would be defective, and, therefore, buyer could not declare himself discharged? A New York court threw that argument out the judicial window in a recent decision: ${ }^{36}$

It would be idiotic to demand consistent failure to deliver a pure product as a basis for cancellation when one undetected delivery of an impure prod-

\footnotetext{
32 Cases cited note 27 , supra.
}

33 Helgar v. Warner's Features, 222 N.Y. 449, 119 N.E. 113 (1918); § 45(2) of the Act.

34 In addition to nonpayment, and refusal to accept goods, seller may also be discharged by buyer's failure to take all his requirements of certain goods from seller when he has contracted to do so. O'Bryan v. Mengel Co., 224 Ky. 284, 6 S.W.2d 249 (1928). The statute does not expressly refer to this class of breach. The result may be supported on the theory that ordering from a third party when buyer was bound to take all his requirements from seller was equivalent to a failure to accept goods froin seller.

35 E.g., Buchman v. Millville Mfg. Co., 17 F.2d 983 (2d Cir. 1927).

36 Hershey Farms v. State, 202 Misc. 105, 110 N.Y.S.2d 324 at 329 (Ct. Cl. 1952), appeal dismissed, 280 App. Div. 903, 116 N.Y.S.2d 494 (3d Dep't 1952). 
uct could cause sickness, epidemic, and death, especially in a State institution whose inmates do not have normal vitality or resistance.

The court indicated that seller's authorities which involved deliveries of defective glass, puzzles, pliers, and pulpwood were not relevant to a case involving delivery of defective food to a hospital. The court also stated $:^{37}$

When an installment contract lias been breached by delivery of one installment of inferior quahity, the answer whether or not the entire contract can be cancelled ... . lies in the facts of each case; . . . in the final analysis the decision is not a matter of law but one of conscience.

The court's argument, in addition to its notable moral power and vigilance for the safety of hospital patients, raises a significant new consideration in applying the statute. Taken from a purely commercial point of view, seller's argument had merit; but the purely commercial point of view does not control when health and safety are at stake.

Unwholesome food has, however, had commercial effects that were sufficient to discharge buyer from his obligation to accept future deliveries. Where buyer and seller contracted for three hundred barrels of flour, which buyer resold to his customers, and seller delivered ten barrels which were unwholesome, the Alabama court placed its decision that buyer was discharged on the ground that buyer's customers had returned the flour with complaints as to its quality. ${ }^{38}$ Apparently a threat to buyer's business reputation can render an otherwise immaterial breach material.

Thus, in deciding whether a buyer is at liberty to cancel his contract, sellers will have to accept the fact that, under the present statute, at least two courts have defined materiality in terms of buyer's standing as regards his customers, or those placed in his care, and not merely with reference to buyer's profit from the contract itself.

Ordinarily, however, the effect of a defective delivery will depend on the extent to which the breach has impaired buyer's expectations from the entire contract. For example, where seller's contract was for seven thousand dozen goatskins to be delivered in two installinents, and nearly half the skins in the first delivery were unmerchantable, the Massachusetts court held that buyer would have to be satisfied with a cause of action for damages for the particular breach and was bound to complete the contract. ${ }^{30}$ But where seller, on a contract for ten thousand pounds of cotton cops ten inches long, delivered cops nine inches long, the Third Circuit sustained buyer's cancellation because mine-inch cops would not fit on his machines and were, for his purposes, useless. ${ }^{40}$

The result, therefore, will depend in many cases on a determination of what buyer could reasonably expect from the whole contract and the extent to which that expectation has been impaired by seller's breach. In sonie

37 Id. at ......., 110 N.Y.S.2d at 329.

38 General Mills v. O'Rear, 239 Ala. 270, 194 So. 823 (1940).

39 Agoos Kid Co. v. Blumenthal Import Co., 282 Mass. 1, 184 N.E. 279 (1932).

40 Paulson v. Bidwell, 278 Fed. 381 (3d Cir. 1922). 
cases one defective delivery is enough to completely shatter a buyer's hopes for profitable dealing under the contract. In other cases, the buyer should be advised to reserve his rights to recover damages for the particular breach and wait for another shipinent before throwing over the agreement.

\section{Delivery of Goods of Improper Quantity}

Deliveries of improper quantity are tested by the same considerations as deliveries of defective goods; that is, the extent to which the delivery impairs buyer's expectations from the entire contract. In the usual case it would seem unlikely that problems requiring the court to look outside buyer's personal position, as where defective quality is involved, will arise where delivery is merely an improper quantity. It can be imagined, however, that short delivery might make it impossible for buyer to meet comimitments with his own customers, thereby injecting his business reputation into the case. However, a case raising this question has not been found.

Suppose that buyer contracts for two hundred tons of flour in half-ton installments, thus making an agreement which contemplates about four hundred deliveries, and one delivery is a few pounds short. The price is to depend on the weight of flour actually delivered. The New York Court of Appeals, in denying buyer's claim for a discharge, said that seller's deviation from the agreement was no more than a "mere technical discrepancy," and in any event, buyer was never bound to pay for more flour than was actually delivered. ${ }^{41}$ But three years earlier the New York Appellate Division had not hesitated to declare that a buyer who received one delivery of forty-two warps of cotton on a fifty warp contract, when the agreement called for much smaller deliveries, was discharged from his obligation to receive future dehiveries. ${ }^{42}$

It may be in this case that the court placed its decision on the ground that many of the warps were delivered late as well as in improper quantity, but the natural tendency to think of quantity breaches in terms of short deliveries should not obscure the possibility that a buyer may be discharged by a delivery of too many goods at one time. If lack of storage facilities or plant capacity to handle the surplus leads a buyer reasonably to believe that the contract will cause him to suffer high storage fees and disrupted production schedules, it would seem that an excessive delivery might produce a discharge. A delivery of too many goods would have an especially damaging effect on buyer if he was caught unprepared to store a commodity that required refrigeration, or some other product for which storage fees are high.

Conversely, it may be inagined that adverse results flowing from short deliveries might include, in addition to an inability to meet contracts with outsiders, an expenditure for advertising or labor which realized no benefit for buyer because seller's product was not on hand. A strong case might also be made by a manufacturer or builder who was working against an

41 Standard Rice Co. v. Klipstein Co., 245 N.Y. 315, 157 N.E. 151 (1927).

42 Herx v. Carlson, 210 App. Div. 417, 206 N.Y. Supp. 174, (1st Dep't 1924). 
approaching winter or rainy season, if a short delivery caused him reasonably to fear that his race with the elements or a contract deadline might be lost by continued dealing with seller.

\section{Late Delivery of Goods}

Late delivery is also tested by extent to which seller's breach has impaired buyer's reasonable expectations from the entire contract. The factual possibilities, varying with buyer's position and seller's misfortunes, are nearly infinite.

A buyer may conduct himself, however, so that late deliveries will not be material. If, on a contract for cotton yarn, a seller had consistently delivered late, could he defeat the buyer's claim for a discharge by showing that the buyer had asked to be relieved of future deliveries because he was overstocked with seller's product? At least one court has concluded that, in view of the buyer's conduct, seller's late delivery was not material. ${ }^{43}$

Note that in this case the court did not hold that buyer's conduct was a waiver of his right to clain strict performance or that he was estopped to show the late deliveries, two doctrines beyond the scope of this article. ${ }^{44}$ A court is not required to hold that the wrongdoer's conduct is legally excused to deny the injured party a discharge. While the question of excuse may arise in an action for damages, the fact that the wrongdoer's conduct is morally justifiable may be enough to make his breach immaterial.

In this connection, suppose that a buyer is a manufacturer of paper boxes and in need of a paper supply that can produce large quantities for his needs. He agrees with seller that seller will build a plant to make paper and that he, buyer, will take the entire production of the proposed plant. Buyer makes it clear to seller that the changeover to a new paper supply will require that seller conform exactly to the first delivery date for paper. Thus far, a failure of seller to deliver the first shipment on time would seem to make a strong case for buyer's discharge. But the reasons seller delivered ninety days late were that buyer failed to aid in financing the three hundred thousand dollar plant called for by the contract as he had promised, an exceptionally hard winter slowed construction of the plant, and, because of war conditions then prevailing, manpower was scarce. The Wisconsin Supreme Court decided that buyer was not privileged to cancel the entire contract; the seller's late delivery was not, in view of all the facts, material. ${ }^{45}$.

The court did not decide that the failure of buyer to assist in financing the plant, or the winter, or scarcity of labor excused seller's nonperformance; the court did hold that seller's high imvestment in the plant and his misfortunes in beginning production, rendered his breach notwithstanding buyer's initial insistence on timely delivery, immaterial.

It would seem that Justice Cardozo, of the New York Court of Appeals, in setting out general considerations for the application of Section 45(2)

43 Buchman v. Millville Mfg. Co., 17 F.2d 983 (2d Cir. 1927).

44 See cases collected in 14 A.L.R. 1233 (1921) and 75 A.L.R. 620 (1931).

45 Kieckhefer Box Co. v. John Strange Paper Co., 180 Wis. 367, 193 N.W. 487 (1923). 
of the Sales Act, in a leading case thirty-five years ago, identified several tests which have been generally followed. He said: ${ }^{46}$

... [W] must know the cause of the default, the length of the delay, the needs of the vendor, and the expectations of the vendee. If the default is the result of accident or misfortune ... . if the breach is willful, ... if the delay has been substantial ....

The effect of the proposed Uniform Commercial Code is discussed below, following the discussion of temporary defenses.

\section{TEMPORARY PRIVILEGE TO SUSPEND PERFORMANCE}

When one party has breached, the other party may decline to declare himself discharged either because his business position requires him to continue dealing with the wrongdoer, or because he doubts the materiality of the wrongdoer's breach. May the injured party withhold payment for a particular delivery, if he is a buyer, or decline to deliver further until buyer pays if he is a seller, and still require the other to perform? It has been said that these limited, temporary defenses lie outside the scope of Section 45(2) of the Sales Act and are, therefore, controlled by the common law. ${ }^{47}$

\section{Privileged Nonpayment}

Some courts have given buyer a privilege to withhold a particular payment in recoupment of damages. ${ }^{48}$ This right was discussed above as an exception to seller's right to be discharged by nonpayment. It was observed that a buyer's privilege to withhold payment may depend on his solvency; the principle that buyer must be solvent before he may withhold payment assumes practical meaming when the effect of a privileged refusal to pay is examined.

If the contract allows buyer to pay for goods several days, or perhaps a month, after delivery, seller has bound himself to extend credit to buyer. Presumably he has taken this into account in assenting to the contract and has satisfied himself that buyer is sufficiently solvent to constitute a good risk for the credit extended. When a court allows a buyer to withhold payment and requires the seller to continue delivery, the seller is required to extend greater credit than he contemplated when he assented to the contract. Where the law places an additional credit risk on the seller, it should be vigilant to make the risk commensurate with buyer's ability to pay.

Two other elements affecting buyer's right to withhold payment may be noted. If buyer believes, or hears from a third party, that seller will not be able to complete his contract, that fact alone is not sufficient to privilege buyer to withhold payment. ${ }^{49}$ But, if the buyer, acting upon a belief that

46 Helgar Corp. v. Warner's Features, 222 N.Y. 449, 119 N.E. 113, 114 (1918).

472 Wirltston, Sales $\$ 465$ (1948).

48 For an early Ninth Circuit decision on this point see Ackerman v. Santa Rosa-Vallejo Tanning Co., 257 Fed. 369 (9th Cir. 1919).

40 National Contracting Co. v. Vulcanite Portland Cement Co., 192 Mass. 247, 78 N.E. 414 (1906) (buyer inay not withhold payment merely because he believes seller will not perform). 
seller will not continue to perform, demands assurances from seller, and receives a reply confirming his belief, the reply will constitute a repudiation. ${ }^{50}$

\section{Privilege to Suspend Delivery Temporarily}

Two early California decisions have given sellers limited defenses to delivery. In Wood v. Mesmer, ${ }^{\text {s1 }}$ seller agreed to print newspapers for buyer. Buyer defaulted in payment, and in seller's action for damages, recovery was asked for some work that had not been delivered to buyer. The court held that seller was not required to have delivered the papers to recover because buyer, being in default, had no right to receive further credit from buyer. It would seen, from the holding, that if buyer had sued seller for nondelivery, seller, could have successfully defended.

Failure of a Califorma buyer to take all his oil requirements from seller when the contract bound him to do so has also given seller a defense to delivery. ${ }^{52}$ The contract was for a fixed price. The court reasoned that both buyer and seller had assumed the risk that the market might move against them to obtain the advantages of a long term supply and market. The court said that the seller should not be required to deliver unless the buyer was willing to be bound to his contract.

If one party has committed a material breach, there should be no objection to allowing the injured party to decline to be discharged and yet refuse to perform until a defect is cured. One early decision ${ }^{53}$ reasoned that the injured party must take a discharge or nothing, because if he elects to waive a material breach and keep the contract alive, he is then bound by the contract as absolutely as the wrongdoer. It would seem, on the contrary, that an election to decline discharge should not necessarily require a complete surrender of all rights to a defense and that no sound reason exists for prohibiting an injured party from merely decreasing the magnitude of his defense, rather than requiring him to choose between a complete discharge and nothing.

The decisions found offer little help in determining if a distinction can be drawn between breaches that give a discharge from future obligation and breaches that give ouly a temporary defense. No case has been found where one defense has been granted and the other denied; no case has been found where a court, even in dictum, has contrasted the two defenses.

EFFECT OF THE PROPOSED UNIFORM COMMERCIAI CODE

The effect of the adoption of the proposed Uniform Commercial Code upon the problem of discharge fron installment contract duties nust be considered because Section 2-612 of the Commercial Code will supercede Section 45(2) of the Sales Act. ${ }^{54}$

50 California Sugar White Pine v. Penoyar, 167 Cal. 274, 139 Pac. 671 (1914).

51 46 Cal. App. 257, 189 Pac. 134 (1920).

E2 Los Angeles Gas \& Electric Co. v. Amalgamated Oil Co., 156 Cal. 776, 106 Pac. 55 (1909).

53 North Shore Lumber v. South Side Lumber, 176 Ill. App. 96 (1912).

$54 \S 45(2)$ of the SaIEs ACT is quoted in note 3 supra. 
Section 2-612(3) of the Commercial Code states:

Whenever nonconformity with respect to one or more installments substantially impairs the value of the whole contract there is a breach of the whole .... (Italics added.)

Thus the Commercial Code would change the installment contract discharge test from a "material breach" to a breach that "substantially impairs the value of the whole contract."

The comment by the writer of the proposed section states: ${ }^{55}$

... Whether the nonconformity in any given installment justifies cancellation as to the future depends, not on whether such nonconformity indicates an intent or likelilood that future deliveries will also be defective, but whether the nonconformity substantially impairs the value of the whole contract. If only seller's security in regard to future installments is impaired, he has the right to demand adequate assurances of proper future performance but has not an immediate right to cancel the contract ....

Under the Uniform Sales Act a reasonable apprehension in seller that buyer will not perform in the future will discharge seller from future obligation..$^{56}$ If the Commercial Code is applied in accord with the framer's intent, no right to cancel arises from such an apprehension unless buyer has repudiated. ${ }^{57}$

Under the Uniform Sales Act we have seen that " . . the cause of the default, ... if the default is the result of accident or misfortune, ... if the breach is willful, ..." ${ }^{58}$ are considerations relevant to the materiality of a breach. The Commercial Code would seem to narrow the test to exclude the moral nature of the wrongdoer's conduct in deciding materiality. ${ }^{60}$ The considerations that control, under the Code, relate only to the extent to which the aggrieved party's expectations from the contract were impaired by the breach. Courts applying the code in a manner consistent with its plain meaning could not hold that the fact that a breach was caused by pure misfortune rendered it immaterial if the value of the entire contract to the aggrieved party was substantially impaired.

This revision in the Sales Act would seem sound. It gives rise to a test which admits of more certain application than the materiality test in the Sales Act, as it has been applied. Prior to litigation, counsel have a difficult task in merely determiming the extent to which a breach has impaired the value of a contract; a requirenient that counsel also measure the wrongdoer's conduct against a moral test may make the task overwhelming. Further, business methods of record keeping can be adapted to determining, before a party assents to a contract, whether the other party has performed in the past, but to ask a businessman to also determine whether the other party is a good "nuoral risk" nuay impose an impossible burden.

55 American Law Institute, Draft of Uniform Commercial Code (1950).

60 Plotnick v. Pennsylvania Refining Co., 194 F.2d 859 (3d Cir. 1952).

57 \$ 2-610 of the Comarercial Code.

58 Helgar Corp. v. Warner's Features, 222 N.Y. 449, 119 N.E. 113 (1918).

59 Thus overruling the Kieckhefer Box Co. case, discussed in the text at note 46 , supra. 
The second revision of the Sales Act accomplished by applying the intention of the Code framers, that a reasonable apprehension that the breaching party will not perform in the future does not discharge, may be of doubtful merit. The writer believes that inferences arising from the questionable nature of the wrongdoer's conduct will be more reliable than later assurances $^{60}$ from the wrongdoer's mouth. A reasonable apprehension that the breaching party will not perform in the future should be a ground for discharge. If the intent of the framers can be laid aside the Code section could be applied to make such reasonable apprehensions grounds for discharge by holding that part of the value of the contract to an injured party was a belief that the other party would perform in the future. Then, conduct that led the injured party to fear for future performance would substantially impair the value of the whole contract and justify a discharge.

Robert S. Daggett*"

${ }^{60}$ See comment following § 2-612 of the Code.

* Member, second-year class. 